\title{
Latent Functions of Brands and Brandings
}

\author{
Hamid Tahmasebifard (Corresponding author) \\ Department of Business Management, Islamic Azad University, Central Tehran Branch \\ Tehran, Iran \\ E-mail: Ham.tahmasebifard.mng@iauctb.ac.ir
}

Mohammad Mahdi Pouyan

Department of Business Management, Islamic Azad University, Central Tehran Branch

Tehran, Iran

E-mail: Mohammad_pouyan@yahoo.com

Mahdie Mirzaagha

Department of Business Management, Islamic Azad University, Central Tehran Branch, Tehran, Iran

E-mail: Mahdieh.mirzaagha@srbiau.ac.ir

Received: March 18, 2018 Accepted: March 26, 2018 Published: April 18, 2018

doi:10.5296/bmh.v6i1.12840 URL: http://dx.doi.org/10.5296/bmh.v6i1.12840

\begin{abstract}
Brands and their positive consequences as an economic constructs, have been well studied. But, in addition to economic, brands are also regarded as a social construct, which has remained fairly unrecognized due to lack of academic investigations. So, the purpose of this paper is to focus on and address negative functions and effects of brands and brandings. With utilizing critical point of view and Merton's functional analysis, this research presents a literature-based conceptual analysis of the negative functions of brands and brandings. The paper identifies that brands have their own demerits (latent functions) in addition to their merits (manifest functions). With referencing to existing literature, this paper identifies some negative effects of brands for societies such as class differences, self-alienation, cultural imperialism, emotional relationships.
\end{abstract}


Keywords: Brand, Anti-branding, Criticism, Cultural imperialism, Emotional relationship, Alienation, Class differences 


\section{Introduction}

Farquhar (1990) has mentioned some instances of employing brands to differentiate among bricks used by clay pits in ancient Egypt. Henceforth, brands have been an inseparable part of human's life; however, never have brands been as influential in human's life as they are today. Brand and branding become the hottest topics in marketing theory and practice. Companies spend billions on planning and implementing branding plans to build brand equity and also preserving their brands (Bavar, Tahmasebifard, \& Kheiry, 2017).

In another word, brands have become a major player of modern society. They penetrate all spheres of our life: economic, social, cultural, sporting, even religion (Kapferer, 2008, p. 9) and affect all aspects of man's life including production and consumption, food and clothing, personality and lifestyle, as well as culture and politics (Fan, 2005).

Brands have brought humans many advantages; they have reduced consumer's costs such as search costs, search time cost, and perceived risks costs (Erdem \& Swait, 1999; Baek \& King, 2011; Keller, 2013, p. 35), simplifying consumers' decision-making process and satisfying them (Jamal \& Goode, 2001; Keller, 2013, p. 35).

Because of this pervasiveness, brands have come under growing criticism (Klein, 1999). As a major symbol of economies and postmodern societies, they can and should be analyzed through different perspectives: macroeconomics, microeconomics, sociology, psychology, anthropology, history, semiotics, philosophy and so on (Kapferer, 2008, p. 9). As an economic construct, brands have been well studied from financial and marketing perspectives, but, in addition to being an economic construct, brands are also considered as a social construct, which has remained fairly unrecognized due to lack of academic studies (Fan, 2005).

According to Merton (1945), the reason might be the fact that brand and branding, as any other action (if branding considered as a set of action taking place in society and brand as a result of these social actions) in society has its enduring relationships with other items within the systems. According to this perspective, any phenomenon through the society has several functions in different aspects. Thus, brand has latent functions besides manifest ones too, and since the concept of brand originates from marketing science, less attention has been paid to its consequences from other perspectives. Therefore, this paper aims at identifying and discussing latent and negative functions of brand and branding. Notwithstanding the fact that generally the goal of marketing in the present era is changing the world into a better place for living (Kotler, Kartajaya, \& Setiawan, 2010, p. 123; Tahmasebifard \& Akbariyeh, 2015), the result of this paper could provide deeper insights about the negative consequences marketing and branding could bring for societies.

\section{Literature Review}

\subsection{Brand and Branding}

Historically, brand has been inextricably just linked to the product (e.g., Gardner \& Levy, 1955) and branding is seen as the process of adding value to the product (Farquhar, 1989). According to the American Marketing Association (AMA), a brand is a "name, term, sign, 
symbol, or design, or a combination of them, intended to identify the goods and services of one seller or group of sellers and to differentiate them from those of competition." However, what is practitioners referring to a brand is more than that - as something that creates a certain amount of awareness, reputation, prominence, and so on in the mind of audiences (Keller, 2013, p. 30; Mirab, Akbariye \& Tahmasebifard, 2015). In this view, a brand is a cluster of functional and emotional benefits that extend a unique and welcomed promise (de Chernatony \& McDonald, 2003).

So, the question is what functions do brands and brandings perform that make them valuable to businesses? Branding literature shows that brands provide value for both customers and businesses. Researches demonstrated that successful branding reduces the information seeking cost and perceived risk by consumers and lays positive effects on perceived value for money and purchase intention (King \& Baek, 2011; Mirabi, Akbariye, \& Tahmasebifard, 2015). Further, there are many pieces of evidence indicative of the positive impacts of branding on consumer loyalty, commitment, satisfaction, word-of-mouth recommendation and decline the switching propensity (Sweeney \& Swait, 2008).

Cretu \& Brodie (2007) found that branding had a positive impact on the perceived quality of the product or service. It was also perceived as providing a product with an identity, a consistent image and as conferring uniqueness (Michell, King, \& Reast, 2001).

Brands' benefits may not be just functional and they can serve as symbolic instrument, allowing consumers to reflect their self-image. Certain brands are associated with certain types of people and thus reflect different values or traits. Consuming such products is a means by which consumers can communicate to others - or even to themselves - the type of person they are or would like to be (Keller, 2013, p. 34). Benefits of brands for both parties (customers and companies) are summarized in table 1.

Table 1. Benefits of brands and brandings for customers and companies

\begin{tabular}{|l|l|}
\hline Benefits for customers & Benefits for companies \\
\hline Higher confidence & Signal of quality \\
\hline Risk/uncertainty reduction & Means of differentiation \\
\hline Increased satisfaction & Means of legally protecting unique features \\
\hline Identification with a strong brand & Source of financial returns \\
\hline Lower information seeking & Facilitating brand extensions \\
\hline Construction of identity (self) & Distribution power \\
\hline Facilitating decision making process & Barrier to entry \\
\hline Identification of source of product & Loyal customers \\
\hline Assignment of responsibility to product maker & Lower switching propensity \\
\hline
\end{tabular}

Source: The authors (based on Hutton, 1997; Michell, King, \& Reast, 2001; Mudambi, 2002; Low \& Blois, 2002; McQuiston, 2004; Bengtsson \& Servais, 2005; Cretu \& Brodie, 2007; Sweeney \& Swait, 2008; Ohnemus, 2009; Wise \& Zednickova, 2009; King \& Baek, 2011; Leek \& Christodoulides, 2011; Keller, 2013). 
Despite these benefits, anti-brand movements have recently received remarkable attraction (Klein, 2009; Fontenelle, 2010). These movements and critiques basically rooted in Frankfurt school of taught and critical theory. Leading Frankfurt figures, Adorno \& Horkeheimer (1976), were of the belief that it is critical theory and dialectic method that pave the way for evolving theories and emerging of new theories over the time (Fontenelle, 2010). Usually critics challenge the existing theories and problematizing them. Over the time, these antitheses become syntheses to develop a new paradigm.

\subsection{Functional Analysis of Social Actions}

The word function has been used in several disciplines with different meaning. It is originated in mathematics where refers to a variable considered in relation to one or more other variables in terms of which it may be expressed or on the value of which its own value depends. In broader terms, this concept is expressed by such phrases as functional interdependence and functional relations so often adopted by social scientists (Merton, 1945).

In this regard, functional analysis is an approach aiming for explaining anthropological facts at all levels of development by their function, by the part which they play within the integral system of culture, by the manner in which they are related to each other within the system (Malinowski, 1926, pp. 132-133).

As a case in point, Kluckhohn (1944) asserted that: "...a given bit of culture is "functional" insofar as it defines a mode of response which is adaptive from the standpoint of the society and adjustive from the standpoint of individual". So, in relation to several system or several levels across the society, phenomenon could lay different effects.

Merton (1957) proposed a paradigm of concepts for functional analysis. He introduced two sorts of functions; namely manifest and latent functions. Manifest functions are those objective consequences contributing to the adjustment or adaption of the system which are intended and recognized by participant in the system. And, latent functions are those neither intended nor recognized. For instances, manifest function of slaveholding in US was the increase in efficiency of South; But latent function of slaveholding was the emergence of new deprived social class which exploited by rich white class of society (Giddens, 2009).

Brands are formed in the mind from all contacts of audiences with marketing activities of a brand. Thus, according to Merton's functional analysis paradigm, as any social action, it has its own latent or unintended functions through the societies. Intended functions (benefits) of brands as an economic construct have been well documented in economics and marketing literature (Erdem \& Swait, 1999; Jamal \& Goode, 2001; Baek \& King, 2011; Keller, 2013, p. 35 ); but the latent (negative) functions of branding has not been documented and there is a need for further investigation to broaden the literature pertained to branding.

\section{Latent (Negative) Functions of Brands and Brandings}

\subsection{Branding and Social Class Differences}

Consumption and how to consume affect how others perceive consumers and how consumers perceive themselves. If one drives a luxury car with a well-known brand or a cheap and 
economic one, this paves the way for the viewers to classify them in their minds, and interact with them based on that classification. Social class or socioeconomic status (SES) refers to the earnings, education or occupational status, and is an infrastructure which enables people to learn their place in the society and compare themselves with others (Ozbilgin \& Pomppe, 2014, p. 152).

From another perspective, segmentation which has become an important milestone for marketing theories is the necessity to complete marketing process. One of the main variables to segment the market is socio-economic variables such as consumers' working situation, income, and education, and demographic variables such as age, life cycle, and civil status (Yankelovich, 1964). This segmentation could act as classifying people in societies.

Social class distinctions are rooted in many assumptions. For instance, power dynamics creates a dichotomy between business owners and the workers they employ. This social structure of haves vs have-nots is manifested through one's assets and properties. The brands that people have or do not have in the society are like labels distinguishing them, and these presumptions organize people's relationships (Smith, 1987, p. 135).

These classifications of people across societies result in social class differences. Class difference could cause many problems especially for the lower class individuals. It is a truism that people have a strong desire to improve their situation. So, they always try to rise into higher classes or at least maintain themselves in the same class. In the long run, it is psychologically difficult to maintain a strong desire for something that manifestly is out of reach (Elster, 2005, p. 122).

The tension is usually resolved by reducing one's level of aspirations and adjusting one's set of values so as to give less importance to those that cannot be realized anyway. This adjusting process will continue to one's beliefs so as to be able to think it possible to get what one wants, but this solution is inherently less stable. Usually, sooner or later, the accumulation of evidence against one's belief will force a readjustment of wants and desires which end up in the problem of class struggle and Marx argued that this is the central problem in understanding social change, because all social conflict reduces to class struggle (Elster, 2005, p. 123).

It is crystal clear that this perceived social distance between people could create regret and suppressed anger toward those who have and those who have not. Further, people are always comparing themselves with others, class difference may bring family instability (Hollingshead, 1950), racial attitude (Hwang, Fitzpatrick, \& Helms, 1998), and irritability towards other classes (Goldenberg, 1971) which can, in turn, give rise to other social problems in the societies.

\subsection{Branding and Self-alienation}

In addition to their distinguishing function and facilitating the process of buying decision making, brands serve psychological functions as well. Brands are used by the consumers, support their self-concept and underpin their personal identity system (Eagle, Dahl, Czarnecka, \& Lloyd, 2015, p. 142), and project their identity and values (Swaminthan, Page, 
\& Gurhan-Canli, 2007). According to De Mooij (2004), identity is an idea that a person has about another person, another person's personality characteristics, another person's body and the values held as important by that person.

To better describe the issue, we should have a look at self-concept and the related concepts. Self-concept is the beliefs one has about his/her attributes and how s/he evaluates them (Solomon, Bamossy, Askegaard, \& Hogg, 2006). The extent to which these attributes are evaluated positively or negatively is known as self-esteem. The relative positivity of one's self-esteem depends on what the consumer perceives of his/her ideal state or the ideal self, and how s/he perceives his/her current state or the actual self (Eagle, Dahl, Czarnecka, \& Lloyd, 2015, p. 143).

In effect, the function of brands in this regard is that they support consumer identity systems by adding attributes of the brand to symbolically represent personal attributes or aspects of their value system so that the brands will improve the consumer's self-concept by filling the gap between their actual self and their ideal self by instilling the attributes of the brand onto them (Belk, 1988). This makes consumers far from what they really are (actual self), and makes them see themselves in the properties which have given them identity, and creates self-alienation.

As used by the philosophers Hegel and Marx, the term alienation denotes self-alienation: to be estranged from one's essential nature (Langenscheidt New College Dictionary, 1973). Therefore, alienation is a lack of self-worth, the absence of meaning in one's life, consequent to being coerced to lead a life without opportunity for self-fulfillment, without the opportunity to become actualized, to become one's self (Honderich, 2005). Marx notes that people see, evaluate, measure, and even recognize themselves within the form of what they have made or achieved and objectify themselves in the world they have created or gained (Marx, 1964, p. 128).

In their production or achievement, people would have objectified their individuality, their specific characters, and, therefore, enjoyed not only an individual manifestation of their life during the activity, but also, when looking at the object, they would have the individual pleasure of knowing their personality to be objective and visible to the senses.

In this regard, Marx utilized the word alienation to describe the condition of workers in capitalist society in which they see themselves as an instrument, a thing, and not a person. He pointed out that our products would be so many mirrors in which we saw reflected our essential nature (Marx, 1844). This is alignment with the social identity theory by which consumers use brands to support their identity system discussed earlier.

Moreover, Askegaard (2006, p. 100) expressed that branding also causes a new consumer to form, a consumer who is brand conscious in the largest sense: a consumer for whom these new symbolic universes gradually become some of the most central parts of his or her identity formation, both individually and in groups.

Now what happens if the connection with possessed brands is not possible due to other different reasons? When the world s/he has created in mind is lost, how would a consumer 
feel, considering that s/he has been living in another world so far and has had a higher self-esteem as a result of owning a brand, hence had an improved self-concept?

\subsection{Branding and Cultural Imperialism}

One of the approaches in brand literature is the cultural approach towards brand management, which focuses on employing cultural forces to develop powerful brands (ultimately brand icons), as well as functions of brands and branding in culture (Heding, Knudtzen, \& Bjerre, 2009 , p. 209). Within the cultural approach, brand is considered as a cultural artifact moving through history (Holt, 2004, p. 215). From this perspective, brand is a storyteller which conveys the cultural meaning, and is an important factor in the intricate web of cultural meanings, manifested in the consumers' collective identity (Heding, Knudtzen, \& Bjerre, 2009 , p. 210). In political and cultural domains, brands have gained power and have become a pivotal topic in globalization-related debates. Askegaard (2006, pp. 92-94) outlined that:

"With the growing impact of market institutions on almost all aspects of our lives, it does not take much imagination to see "brands" and "branding" as part of an increasingly dominant market economic and commercial ideoscape, carried by organizations such as WTO, by marketing and management practices and by the contemporary sovereign status of the liberal market economy. As [part of] such an ideoscape, branding is becoming central to the structuring of commercial and economic activitites in still larger parts of the world. One may argue that brands are among the most significant ideoscapes in the globalization processes."

In this regard, brand value is created through playing an active role in mainstream culture. The brand is subjected to social and cultural changes and thereby influenced by changes completely outside the brand manager's control. On the one hand, this means that the marketer is not the only author behind the brand meanings.

On the other, a brand manager who manages to understand the most relevant cultural currents is able to write the proper "manuscript" for the brand to benefit from pressing cultural issues of the time. In that sense, the brand gains competitive power by providing the consumer with the appropriate web of associations and the most powerful myths of its time (Heding, Knudtzen, \& Bjerre, 2009, p. 211).

Horkheimer \& Adorno (1996) called iconic brands as mass culture industries and Holt (2002) called it generator of consumer culture which refers to the dominant mode of consumption that is structured by the collective actions of firms in their marketing activities. Starbucks is often referred as a cultural icon or a brand icon and also is subjected to criticism for acting as a cultural imperialist and for not taking interest and paying enough attention to fair trade.

Its success hence goes hand in hand with being one of the brands that is most fiercely criticized by the anti-brand movement: "Starbucks has become a cultural icon for all the rapacious excesses, predatory intentions, and cultural homogenizations that social critics attribute to globalizing corporate capitalism" (Thompson \& Arsel, 2004, p. 631).

\subsection{Branding and Emotional Relationships}

Research has shown that consumers establish relationships with brands as in human 
relationships (Fournier, 1998). For instance, a study carried out by Kleine, Kleine, \& Allen (1995) demonstrated a type of emotion in consuming objects. Thompson \& Phua (2005) discussed that when people place these objects in the central position of their lives, they are emotionally attached to them.

The concept of emotional attachment to brands originates from the attachment theory (Bowlby, 1979) which states that the degree to which individuals are strongly attached to a person (or a brand) determines their level of commitment to the relationship and the level of acceptance of sacrifices involved in the relationship. Attachment is the process of establishing emotional bonding (Collins \& Read, 1990) and developing it through consistent experiences with an entity (for example, a person or a brand) (Perry, 1998).

Emotional attachment to a brand is indicative of the proximity of a consumer's self to a brand in terms of strong emotional and cognitive perception in the consumers' minds (Fournier, 1998; Park, MacInnis, \& Priester, 2006). Further above emotional attachment is brand love which is a very strong emotional experience of a brand and the relationships between brands and consumers (Hwang \& Kandampully, 2012). The concepts of emotional attachment and brand love are so extremely similar that Carroll \& Ahuvia (2006, p. 81) consider brand love to be a degree of passionate emotional attachment a satisfied consumer has for a particular trade name. Individuals who love a brand must have it, are passionate about it, get a quasi-erotic feeling from using it, and spend money on it (Brown, 1998).

The literature on marketing has well explored the positive consequences of emotional relationships with brands. All might have experienced the emotional attachment or love for objects or people in life. Perhaps the most tangible one is the love for one's parents. Regardless of pleasant experiences of emotional attachments and love for individuals, when the objects or people are not available for some time for any reason, what will happen to the other person in that relationship?

How will you feel when you lose an object which has been at your house for a long time, and with which you have established an emotional nostalgic relationship?

\section{Discussion and Conclusion}

In this conceptual paper, we have addressed four negative functions of branding in human societies; class difference, self-alienation, cultural imperialism, and emotional relationships.

As discussed, the brands people have or do not have in the society are like labels distinguishing them from one another, and these presumptions organize people's relationships (Smith, 1987, p. 135), and this contributes to the class difference and the distance between social classes in societies. On the other hand, based on Marx's views, individuals see and evaluate themselves within what they have achieved or created and the reflection of these creatures in their life (Marx, 1964, p. 128).

With respect to the role of brands in supporting consumers' self-concept and their identity system (Eagle, Dahl, Czarnecka, \& Lloyd, 2015), we argued that brands could make consumers have hallucinations about their actual self, and instill self-alienation onto them. 
Cultural imperialism is another latent function of brands in societies which was mentioned earlier.

From a cultural perspective, brands have influenced the culture of different societies, changed their lifestyles, and affected their ancient cultures (Holt, 2002), and eventually brands have caused consumers' attachment and dependence. Any attachment or dependence may seem enjoyable as long as relationship continues with the object or person; however, it prepares the ground for either side's abuse, and also causes distress and anxiety in the case of a break-up.

Advances in science across history have been a result of dialectics between theses and anti-theses. Through time, new information has been discovered and become the anti-theses of the existing theories and the cause for the synthesis of the new ones. The resulting synthesis or the new theory can be promoted to become a formal theory (Grover \& Glazier, 1986).

So, as discussed, despite the many advantages they bring for individuals, brands, like any other phenomenon, have negative and latent functions as well. In spite of sufficient studies about the consequences of brands from economic and marketing perspectives, few studies have been carried out on brands as social constructs and their effects that it could have for human being generally (Fan, 2005).

Therefore, in this study, by adopting a critical approach, and as based on Merton's theory of functionalism (1957) which briefly outlined that every phenomenon has latent functions in addition to the obvious ones, we seek to identify latent and negative consequences of brand and branding for people and societies. Based on the evidence in the literature on marketing and sociology, we identified four latent functions of brands for societies.

From a practical point of view, since one of the aims of marketing in the present era is changing the world into a better place for living through emphasis on promoting humanitarian and social-cultural activities (Kotler, Kartajaya, \& Setiawan, 2010, p. 123; Tahmasebifard \& Akbariyeh, 2015), the recognition of the existing problems and contradictions in marketing can be of a substantial help to clarify this science and change the approaches to achieve this goal.

Academically, this research has contributed to the literature by bringing up aspects of brands which have been neglected so far. Challenging the existing hypotheses, the present study employed both problematization and gap-spotting as methodologies for generating research questions (Alvesson \& Sandberg, 2011), and discussed a topic which has been so far neglected in marketing literature, and which can be effective in complementing the growing body of this science. This research identified aspects of brands functions in societies which can be reviewed in experimental studies either in sociology or in marketing, and add to the current knowledge in brand management.

\section{References}

Askegaard, S. (2006). Brands as a global ideoscape. In J. E. Schroeder, \& M. Salzer-Morling (Eds.), Brand Culture. London: Routledge. 


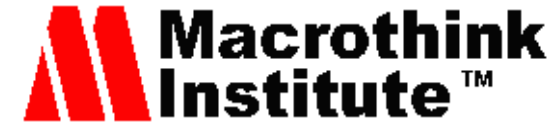

Business and Management Horizons

ISSN 2326-0297

2018, Vol. 6, No. 1

Bavar, A., Tahmasebifard, H., \& Kheiry, B. (2017). Studying the Factors Affecting Consumers Complicity with Counterfeit Products. Business Management and Strategy, 8(1), 39-57. https://doi.org/10.5296/bms.v8i1.10648

Baek, T. H., \& King, K. W. (2011). Exploring the consequences of brand credibility in

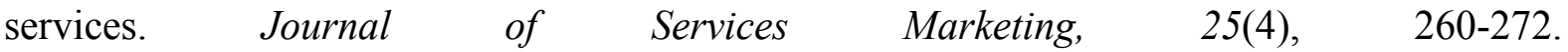
https://doi.org/10.1108/08876041111143096

Belk, R. (1988). Possessions and the extended self. Journal of Consumer Research, 15, 139-169.

Bengtsson, A., \& Servais, P. (2005). Co-branding on industrial markets. Industrial Marketing Management, 34, 706-713.

Bowlby, J. (1979). The Making and Breaking of Affectional Bonds. London: Tavistock.

Brown, S. (1998). Romancing the market: sex, shopping and subjective personal introspection. Journal of Marketing Management, 14(7), 783-798. https://doi.org/10.1362/026725798784867644

Carroll, B. A., \& Ahuvia, A. C. (2006). Some antecedents and outcomes of brand love. Marketing Letters, 17(2), 79-89. http://dx.doi.org/10.1007/s11002-006-4219-2

Cretu, A. E., \& Brodie, R. J. (2007). The influence of brand image and company reputation where manufacturers market to small firms: A customer value perspective. Industrial Marketing Management, 36, 230-240. https://doi.org/10.1016/j.indmarman.2005.08.013

Collins, N. L., \& Read, S. J. (1990). Adult attachment, working models and relationship quality in dating couples. Journal of Personality and Social Psychology, 58(4), 644-663. http://dx.doi.org/0022-3514/90/S00.75

Cornelius, I. (1996). Meaning and Method in Information Studies. Norwood, NJ: Ablex.

De Mooij, M. (2004). Consumer Behaviour and Culture: Consequences for Global Marketing and Advertising. London: Sage Publications.

Heding, T., Knudtzen, C. F., \& Bjerre, M. (2009). Brand Management: Research, Theory and Practice. New York: Routledge.

Hollingshead, A. B. (1950). Class Differences in Family Stability. The Annals of the American Academy of Political and Social Science, 272, 39-46.

Holt, D. B. (2009). Why Do Brands Cause Trouble? A Dialectical Theory of Consumer Culture and Branding. Journal of Consumer Research, 29(1), 70-90. http://dx.doi.org/10.1086/339922

Fournier, S. (1998). Consumers and their brands: developing relationship theory in consumer research. Journal of Consumer Research, 24(4), 343-374. http://dx.doi.org/10.1086/209515

Goldenberg, I. (1971). Social Class Differences in Teacher Attitudes toward Children. Child Development, 42(5), 1637-1640. 
Giddens, A. (2009). Sociology (6th ed.). Cambridge, UK: Polity Press.

Grover, R., \& Glazier, J. (1986). A conceptual framework for theory building in library and information science. Library and Information Science Research, 8, 227-242.

Holt, D. B. (2004). How Brands become Icons: The Principles of Cultural Branding. Boston MA: Harvard Business School Press.

Horkheimer, M., \& Adorno, T. W. (1996). Dialectic of Enlightenment. New York: Continuum. Hutton, J. G. (1997). A S of Brand Equity in an Organizational-buying Context. Journal of Product and Brand Management, 6, 428-439.

Hwang, J., \& Kandampully, J. (2012). The role of emotional aspects in younger consumer-brand relationships. Journal of Product \& Brand Management, 21(2), 98-108. https://doi.org/10.1108/10610421211215517

Hwang, S. S., Fitzpatrick, K. M., \& Helms, D. (1998). Class Differences in Racial Attitudes: A Divided Black America? Sociological Perspectives, 41(2), 367-380. http://dx.doi.org/10.2307/1389482

Kotler, P., Kartajaya, H., \& Setiawan, I. (2010). Marketing 3.0: From Products to Customers to the Human Spirit. New Jersey: John Wiley \& Sons.

Kleine, S. S., Kleine, R. E., \& Allen, C. T. (1995). How is a possession "me" or "not me"? Characterizing types and an antecedent of material possession attachment. Journal of Consumer Research, 22(3), 327-43.

Leek, S., \& Christodoulides, G. (2011). A literature review and future agenda for B2B branding: Challenges of branding in a B2B context. Industrial Marketing Management, 40, 830-837.

Low, J., \& Blois, K. (2002). The evolution of generic brands in industrial markets: the challenges to owners of brand equity. Industrial Marketing Management, 31, 385-392.

McQuiston, D. H. (2004). Successful branding of a commodity product: The case of RAEX Laser Steel. Industrial Marketing Management, 33, 345-354.

Marx, K. (1964). Economic and Philosophical Manuscripts. In Karl Marx: Early Writings, edited and translated by T. B. Bottomore. New York: McGraw-Hill.

Mirabi, V., Akbariyeh, H., \& Tahmasebifard, H. (2015). A Study of Factors Affecting on Customers Purchase Intention: the Agencies of Bono Brand Tile in Tehran. Journal of Multidisciplinary Engineering Science and Technology, 2(1), 267-273.

Michell, P., King, J., \& Reast, J. (2001). Brand values related to industrial products. Industrial Marketing Management, 30(5), 415-425.

Mudambi, S. (2002). Branding Importance in Business-to-Business Markets Three Buyer Clusters. Industrial Marketing Management, 31, 525-533. 


\section{Macrothink}

Business and Management Horizons

ISSN 2326-0297

2018, Vol. 6, No. 1

Ohnemus, L. (2009). B2B Branding: A financial burden for shareholders? Business Horizons, $52,159-166$.

Perry, B. D. (1998). Maltreated Children: Experience, Brain Development and the Next Generation. New York, NY: Norton \& Company.

Park, C. W., MacInnis, J. D., \& Priester, J. (2006). Brand attachment: constructs, consequences, and causes. Foundations and Trends in Marketing, 1(3), 191-230. http://dx.doi.org/10.1561/1700000006

Solomon, M., Bamossy, G., \& Askegaard, S. (2005). Consumer Behaviour: A European Perspective. London: Prentice Hall.

Smith, D. (1987). The Rise and Fall of Monetarism. Harmondsworth, London: Penguin.

Swaminathan, V., Karen, L. P., \& Gu"rhan-Canli, Z. (2007). "My" brand or "our" brand: the effects of brand relationship dimensions and self-construal on brand evaluations. Journal of Consumer Research, 34(2), 248-259. http://dx.doi.org/10.1086/518539

Sweeneya, J., \& Swait, J. (2008). The effects of brand credibility on customer loyalty. Journal of Retailing and Consumer Services, 15, 179-193.

Tahmasebifard, H., \& Akbariyeh, H. (2015). Corporate social responsibilities and marketing. WALIA journal, 31(S2), 117-122.

Thompson, C. J., \& Arsel, Z. (2004). The Starbucks brandscape and consumers' (anticorporate) experiences of glocalization. Journal of Consumer Research, 31, 631-642. http://dx.doi.org/10.1086/425098

Thomson, M., MacInnis, D. J., \& Park, C. W. (2005). The ties that bind: measuring the strength of consumers' emotional attachment to brands. Journal of Consumer Psychology, 15(1), 77-91. https://doi.org/10.1207/s15327663jcp1501_10

Wise, R., \& Zednickova, J. (2009). The rise and rise of the B2B brand. Journal of Business Strategy, 30(1), 4-13. https://doi.org/10.1108/02756660910926911

\section{Copyright Disclaimer}

Copyright for this article is retained by the author(s), with first publication rights granted to the journal.

This is an open-access article distributed under the terms and conditions of the Creative Commons Attribution license (http://creativecommons.org/licenses/by/3.0/). 